\title{
Catarrhine Evolution in China
}

\author{
Huang Z-P ${ }^{1,2}$, Pan $\mathrm{H}^{1,2}$, Zhang $\mathrm{H}^{3}, \mathrm{Li}^{2,3,4 *}$ and Pan \\ $\mathbf{R}^{2,3,5 *}$ \\ Institute of Eastern-Himalaya Biodiversity Research, \\ Dali University, Dali, Yunnan, China \\ ${ }^{2}$ International Centre of Biodiversity and Primates \\ Conservation, Dali, Yunnan, China \\ ${ }^{3}$ Shaanxi Key Laboratory for Animal Conservation, \\ College of Life Sciences, Northwest University, Xi'an, \\ China \\ ${ }^{4}$ Center for Excellence in Animal Evolution and Genetics, \\ Chinese Academy of Sciences, Kunming, China \\ ${ }^{5}$ School of Human Sciences, The University of Western \\ Australia, Perth, Australia \\ *Corresponding author: Baoguo Li, International \\ Centre of Biodiversity and Primates Conservation, Dali, \\ Yunnan 671003, China; Shaanxi Key Laboratory for \\ Animal Conservation, College of Life Sciences, Northwest \\ University, Xi'an 710069, China; Center for Excellence \\ in Animal Evolution and Genetics, Chinese Academy of \\ Sciences, Kunming 650223, China
}

Ruliang Pan, International Centre of Biodiversity and Primates Conservation, Dali, Yunnan 671003, China; Shaanxi Key Laboratory for Animal Conservation, College of Life Sciences, Northwest University, Xi'an 710069, China

Received: August 31, 2021; Accepted: October 01, 2021; Published: October 08, 2021

\section{Introduction}

Among the primates in China, fossil records of the earliest primitive primates unearthed in Hunan and Hubei provinces about 55 mya imply that prosimians originated in China [1-3]. That is more impressive considering numerous archaeological sites bearing primates and hominins have been found in China, including 103 for macaques (Macaca) alone, and more than 70 for hominins (Homo erectus and H. sapiens), and more than 1,000 for Palaeolithic cultural remains. As for the catarrhines, including Old World monkeys (Macaques and Colobines), and apes (gibbons and great apes), and archaic humans, their ancestors came from Africa during the Miocene, Pliocene, and the Early Pleistocene [4-8]. China has provided a unique mainland for their further evolutionary development in East and Southeast Asia through dispersion, speciation, and radiation, especially regarding early archaic human development involving Homo erectus and early H. sapiens [9-11]. In other words, China can provide one of the ideal regions in this globe to analyze the relationship between humans and nonhuman primates (primates thereafter), and clarify some controversial issues in their evolution, biodiversity, phylogeny, natural selection, and environmental adaptation [12-15].

Unfortunately, those studies have not been conclusively and integrally analyzed by focusing on primates and humans simultaneously. Thus, with fossil data of archaic humans and primates, and that of the extant primates, this study aims to explore the evolutionary coexistence between the two groups; identify when and how primate diversity has significantly changed, and clarify whether the modern human (H. sapiens) evolved from China proposed by different anthropologists. Such an effort is critically required to fully understand the evolutionary development and diversity changes of the catarrhines in East Asia.

\section{Material and Methods}

Fossil records are used to explore paleo-regional diversity disparity (Western, Central, and Eastern China). Since such records for the colobines and apes are scarce, those of the macaques found in the Pliocene, Pleistocene, and the Early Holocene, are used to represent paleo-diversity profiles of the primates in China. Database of the archaic humans (Pleistocene and Early Holocene) are utilized to study the scenarios of Homo erectus and H. sapiens. Fossil databases were collected from journal publications. Another database containing the extant primates (macaques, colobines, and gibbons) from Dr. Zhigang Jiang is used to illustrate China's contemporary primate diversity scenarios.

SPSS Version 20 are used to illustrate the regional diversity disparity of the primates and humans schematically.

\section{Results}

\section{Primates}

Fossil diversity profile (a proportion of the total recorded sites bearing Macaca) uncovered in China during the Pliocene, 


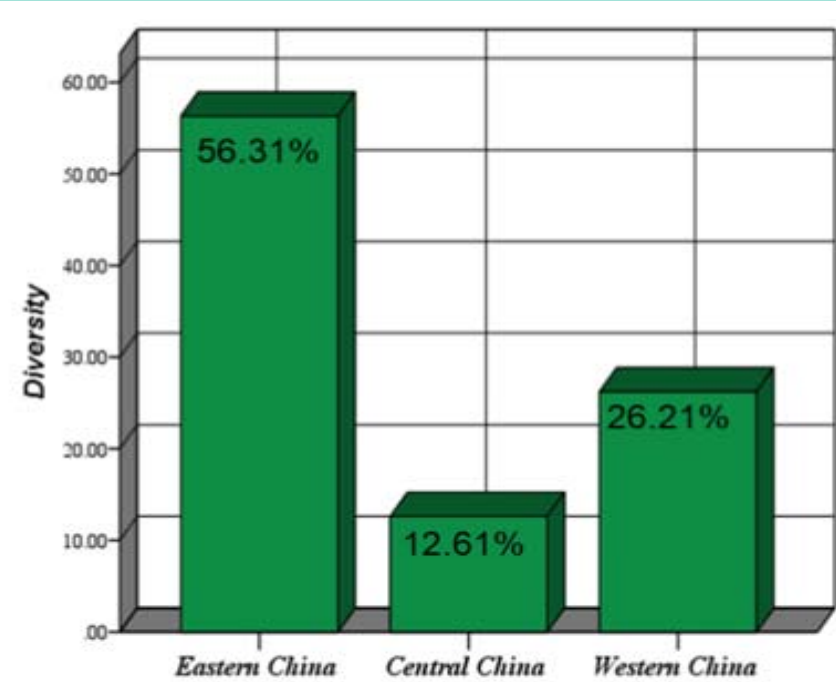

Figure 1: A diversity profile of fossil macaques uncovered in the Pliocene Pleistocene, and early Holocene in China, based on the database from [62] Eastern China: Hebei, Beijing, Liaoning, Shandong, Guangdong, Jiangsu, Guangxi, and Zhejiang; Central China: Hubei, Shanxi, Anhui, Shanxi, Henan, Shanxi and Anhui; and Western China: Inner Mongolia, Yunnan, Shaanxi, Sichuan, and Guizhou.

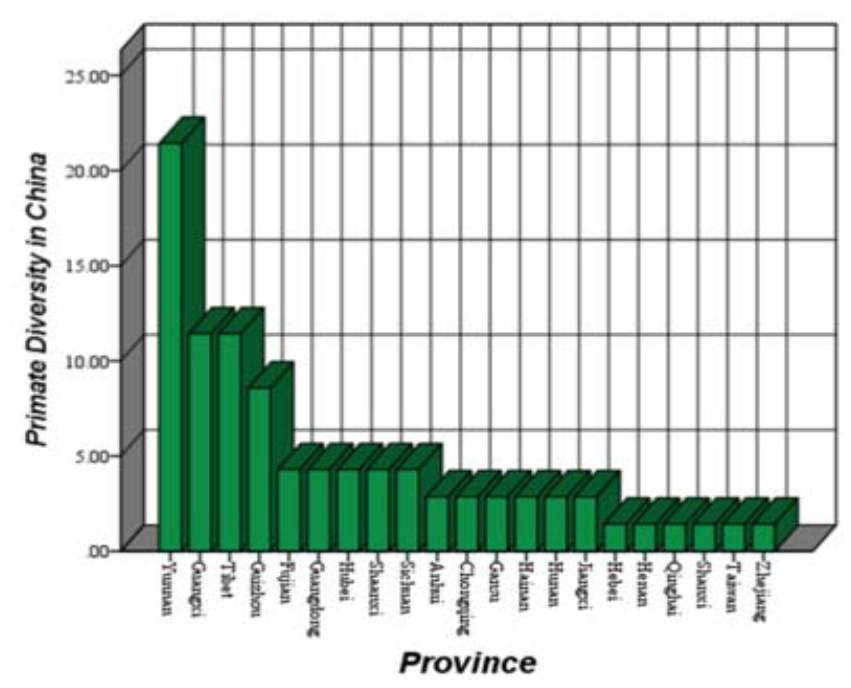

Figure 2: Extant primate diversity in China is progressively decreased from Western China, characterized by the plateaus and high mountains, to the coastlines in Eastern China.

Pleistocene, and the Early Holocene is illustrated in Figure 1. Eastern China maintained the highest diversity (56.31\%), followed by Western China (26.2\%). Central China had the lowest diversity (12.61\%). Their current diversity profile is illustrated in Figure 2. It is clear that Western China, particularly Yunnan, Guangxi, Tibet, and Guizhou, maintain the most remarkable diversity, which is gradually diminished from Central to Eastern China.

\section{Archaic humans}

Their diversity patterns are presented in Figure 3. As for the $H$. erectus, its fossil locations are dominant in Western China. Central and Eastern China show about the same level. However, that of the $H$. sapiens is quite different - its diversity gradually decreases from

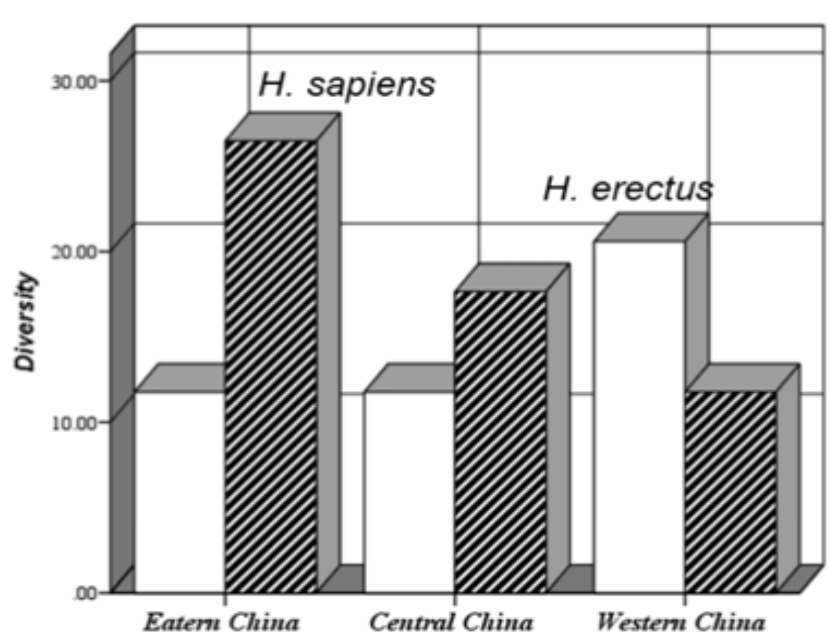

Figure 3: Archaic human diversity during the Pliocene, Pleistocene, and the Early Holocne in China, data from $[52,55,63]$

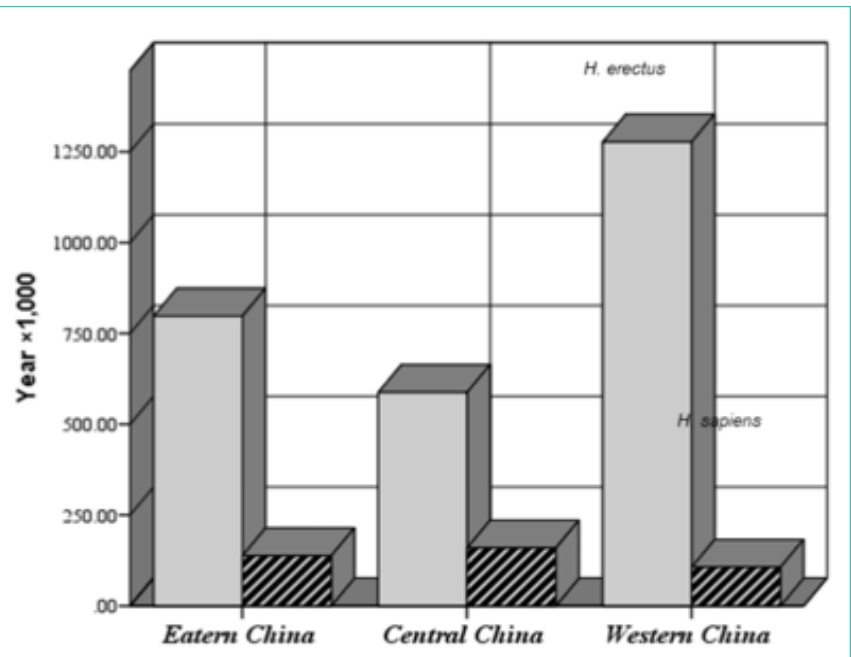

Figure 4: Age variation of the archaic humans in China, data from $[52,55,63]$

Eastern to Western China. Regional fossil age differentiation of the archaic Homo is provided in Figure 4. The age of the H. erectus in Western China is older than that in Eastern and Central China. As for the age of H. sapiens, Western China has the youngest fossils compared with the other two regions.

\section{Discussion}

\section{Primate evolution}

As for the Old World monkeys, macaques and colobines separated about 14 mya [4] or before ten mya [5] in Africa, then migrated through Eurasia to enter Western China at different times, based on which they completed further dispersion and radiation in East and Southeast Asia [6-8].

\section{Macaques}

According to [9], Mediterranean-Eurasia species, or ancestors of the Barbary macaques now living in northern Africa, started their long journey in the Miocene about 10 mya. They might have entered an area covering the southeast Qinghai-Tibet Plateau and Mts. 


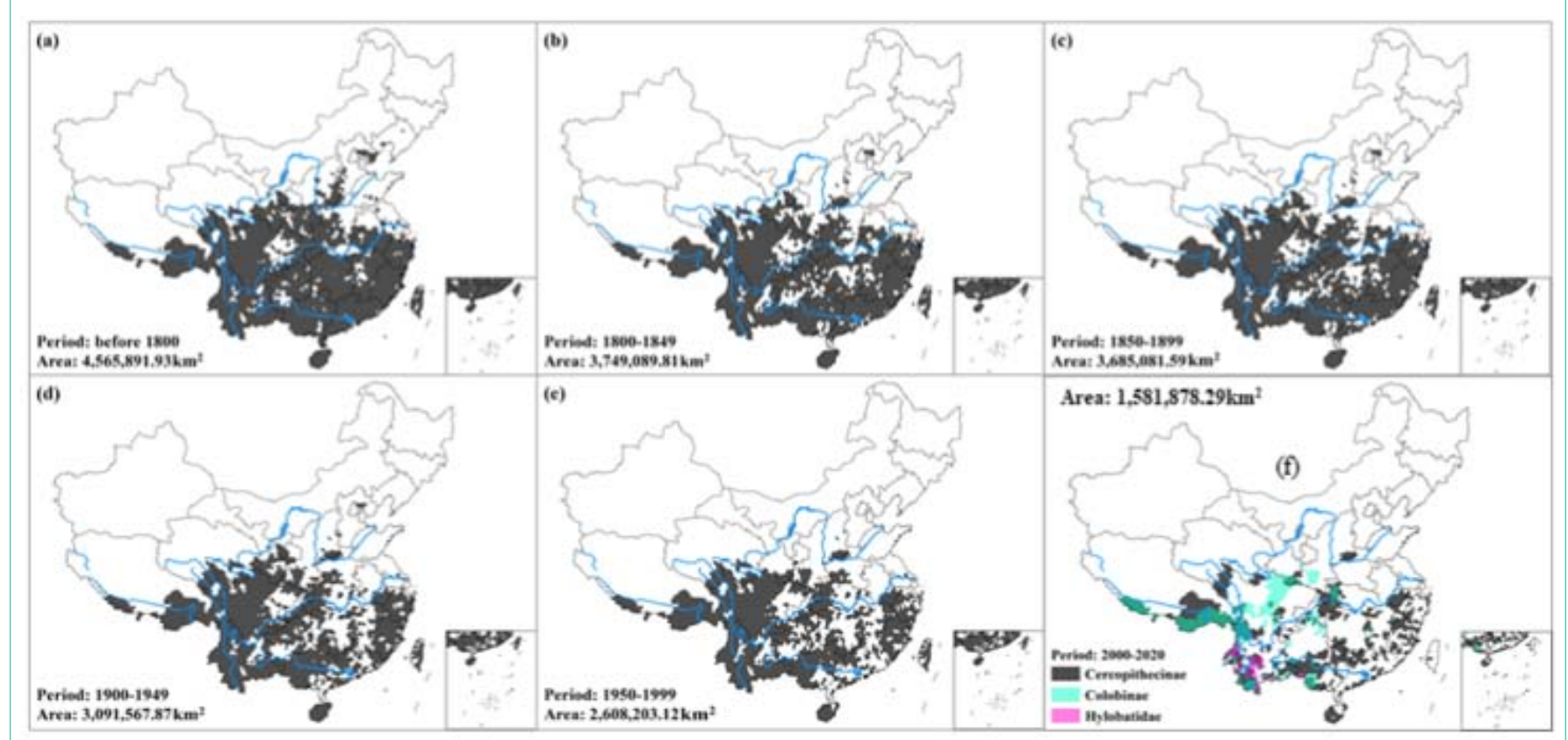

Figure 5: Historically reduced primate diversity in China since 1175, cited from [45] with permission.

Hengduan in China and northern Myanmar in the late Pliocene [8], then widely radiated in East and Southeast Asia, including Taiwan, Korea, and Japan. Nineteen species were derived in the same genus (Macaca) during the evolutionary development - eight of them are now allocated in mainland China and Twain, namely, M. leonina, $M$. arctoides, M. assamensis, M. thibetana, M. mulatta, M. cyclopis, $M$. leucogenys, and M. munzala, e.g. [8,10-14]. The related fossils have been found in China, South Korean, and Taiwan (M. anderssoni, M. robusta, and $M$. jiangchuanensis).

\section{Colobines}

The extant taxa in China include 12 species: Pygathrix nemaeus (extirpated recently), Trachypithecus francoisi, Trachypithecus leucocephalus, Trachypithecus shortridgei, Trachypithecus crepusculus, Trachypithecus pileatus, Trachypithecus phayrei, Semnopithecus schistaceus, Rhinopithecus bieti, Rhinopithecus brelichi, Rhinopithecus roxellana, and Rhinopithecus strykeri [14]. They may have reached Western China in the Late Miocene, e.g., [15]. The oldest colobine fossil record was Mesopithecus in Europe, western and eastern Asia [15-17]. A most recent proposition on the formation of Asian colobines was provided based on mt DAN evidence [18]: they approached East Asia in the Late Miocene, and some species radiated to alternative regions in Southeast Asia, such as the ancestors of the odd-nosed forms (Rhinopithecus, Nasalis and Pygathrix) and the langurs (Trachypithecus/Presbytis and Semnopithecus), leading to the extant taxa in Bangladesh, India, Burma, China, and Sundaland [7].

\section{Apes}

Apes in Eurasia appeared approximately 17 million years ago [19]. They may have arrived in Western China during the middle and late Miocene (12-6 mya) [20]. Fossil Asian great apes (Pongo, Gigantopithecus, and Lufengpithecus) and lesser apes (Hylobates) were unearthed in the late Miocene and Pleistocene in southern China [20-22]. The ancestors of the great apes include Lufengpithecus in the Late Miocene (12.0-6.0 mya) at five localities of Yunnan in Western China $[20,23,24]$.

The distribution of great apes appears to retreat southward during the early Pleistocene, around 2.0 mya [25], followed by the shifts of lesser apes (Hylobates) that remained relatively abundant in the tropical zone in the Pleistocene. Such a significant shift was caused by climate change accelerated since the Late Pleistocene [26]. Despite their success for about 10 million years, the larger-bodied great apes Lufengpithecus taxa went extinct in China in the Late Miocene (6.0 mya). Gigantopithecus disappeared by the end of the Pleistocene, whereas gibbons, the smallest-bodied ape, survived in the southern subtropical zone through the Late Pleistocene and Holocene [27,28].

Given the incomplete nature of understanding ape fossil records in East Asia, their origin and dispersal patterns remain poorly understood [29]. The primary debate is whether gibbons and great apes are part of an ancient lineage, evolved in the middle Miocene in Africa (around 10 mya), or gibbons originated independently in Asia [30,31]. DNA evidence indicates that gibbons split from great apes before the African and Asian great ape divergence in Africa some 13.1 to 9.8 mya [29] or Eurasia between 14-16 ma [32,33]. Assuming a Eurasian origin for gibbons, they may have gotten into Western China in the late Miocene or early Pliocene. Gibbon-related fossils, such as Dionypithecuss huangouensis were found in Jiangsu in Eastern China, and Laccopithecus robustus in Lufeng, Yunnan in Western China, dated the Late Miocene [30]. They were regarded as being associated with the extant species, Nomascus concolor, in Southern China. Another fossil species (Bunopithecus sericus) found in Chongqing in Western China in the Pleistocene deposit is considered close to the extinct crown hylobatid and the one possibly representing a sister taxon to Hoolock [34]. Based on the studies of molecular data, it appears that gibbon radiation is relatively recent and rapid, either as a vicariant event or extremely fast radiation [35-37]. Some southeast 
and western China regions, such as Yunnan, Jiangsu, Sichuan, Inner Magnolia, and Guangdong, Guangxi, and Hainan, appear to have played an essential role in gibbons' origins and dispersal [30,38-42].

What is illustrated in Figure 1 and 2 indicate that primates in China have experienced quite different evolutionary development before and after the Early Holocene. They reached every corner of mainland China and Taiwan, indicated by Eastern China's highest abundance (56.31\%) in Figure 1. That Western China, where primates initiated the continental dispersion and radiation, does not show the highest diversity, must be associated with the violent tectonic movements of the region since the Late Miocene or Early Pliocene, particularly regarding the Qinghai-Tibet Plateaus and Yun-Gui Plateau [43] so that many animal fossils were buried during the uplift $[44,45]$. That Central China remains a minor proportion must be associated with the fact that the region had been remarkably impacted since the Late Pleistocene, following the appearance of archaic humans in the region [45] (please see below). Figure 2 presents the current primate diversity profiles in China; unlike Figure 1, it illustrates a gradually decreased diversity from Western to Eastern China, indicating that most of the populations/taxa in Eastern and Central China have disappeared, and Western China is the place remaining most of the taxa and populations. This phenomenon corresponds to what has been revealed based on available historical records: primate extirpation and geographic reduction in China appeared about 850 ago [45] (Figure 5). They started shrinking from north to south and from east to west, and a significant disappearance was accelerated since the second half of the last century (Figure $5 \mathrm{e}$ and $5 \mathrm{f}$ ). So that more than $84.4 \%$ of gibbons' distribution has been lost $[14,46]$. Among 25 species of primates in China today, $80 \%$ are threatened. A modeling expectation indicates that the agricultural expansion to the end of this century could result in about 51 to $87 \%$ of China's primates disappeared by 2100 [14]. Thus, primates in China are primarily on the verge of extinction unless tangible conservation strategies and tactics and forceful managerial means must be implemented sooner rather than later.

Dreadful diversity reduction of the primates in China could have started about 50-70,000 years ago, caused by further extension and occupation of modern humans (Homo sapiens) [45]. Many archaeological records from Henan, Shanxi, Hubei, Chongqing, Zhejiang, Guizhou, and Guangxi indicate that early modern humans occupied continental China 50 or $100 \mathrm{kyr}$ ago in Central and Eastern China $[47,48]$. Thus, the first measurable impact of modern humans on China's primates and other animals may begin some 7,000-9,000 years ago following more sophisticated tool technology $[14,49,50]$. Beginning about 2,000-3,000 years ago, China's first dynastic rulers resulted in significant changes to the landscape, deforestation due to increased human population size, followed by sizeable mammalian population extinction [51], particularly the shrunken gibbons' distribution areas [46].

\section{Archiac Homan evolution}

Chinese prehistory may have started about 2.12 mya at Shangcun, Lantian in Shaanxi province, considering the oldest Palaeolithic recognizable tools [52] or 1.36 or 1.7-1.6 mya in the Nihewan Basin, next to Beijing $[53,54]$. That indicates that tool-making early Homo had reached the area during the Later Pliocene or Early Pleistocene,

\section{$2.12 \mathrm{Ma}[52]$.}

What is presented in Figure 3 indicates that Western China shows the most remarkable diversity for $H$. erectus, which is quite different from the scenario of the primates represented by the macaques (Figure 1). That must be related to the fact that this species arrived in Western China about 2.12 mya, referring to Palaeolithic tools [52] or 1.36 or 1.7-1.6 mya based on the fossil records aforementioned $[53,54]$. That was much later than the macaques, colobines, and apes did. Thus, it is likely that fewer fossil sites of $H$. erectus were buried by the violent tectonic movement in Western China. In Yuanmou, Western China, Hominin species include the taxa of African $H$. erectus and $H$. habilis, dated about 1.9-1.66 ma. They were proposed to have used the stone artifacts made with Oldowan technology [55]. Their followed eastern and southern dispersions resulted in numerous hominin sites in China and other parts of Asia. Two are at Nihewan Basin and Zhoukoudian, Northern China, next to Beijing [56-58]. That explains why H. erectus in Western China is older than those found in the other two regions (Figure 4).

As for the appearance of modern humans (early H. sapiens) in China, there have been two hypotheses: 'Out of Africa,' implying that it first appeared in Africa, then migrated to Eastern Asia in the Late Pleistocene $(126,000 \pm 5,000$ years ago). That is evidenced by their fossilized remains and cultural/technological inventory (stone tools) found in China (e.g., Yuanmou, Dali, Maba, Peking, etc.) and India (Narmada) [59]. Another hypothesis is multiregional development: modern humans in China and other parts of Southeast Asia were derived from regional H. erectus, which is supported by the evidence found in Dali in Shaanxi Provinces, Zhoukoudian, Daoxin in Hunan, Zhirendong in Guangxi, Yunxian in Hubei - they are located in Eastern and Central China [60]. Such a regional origin proposition can be backed up by the diversity profile illustrated in Fig.3, in which East China is prosperous with fossil H. sapiens than Central China. Western China, however, shows fewer fossil sites, which is different from the scenario of its ancestor $(H$. erectus) in the same figure. That matches what is illustrated in Figure 4 - the fossils of $H$. sapiens found in Eastern and Central China are older than those found in Western China. Another newly named human species, Homo longi, found in the Middle Pleistocene in Harbin City, Heilongjiang Province, is considered closely associated with H. sapiens in Central China [61]. Thus, what is provided in Figure 3 and 4 clarify the hypothesis that $H$. sapiens appeared in China came from the same continent.

\section{Acknowledgments}

This project was supported by the Strategic Priority Research Program of the Chinese Academy of Sciences (XDB31020000); the Natural Science Foundation of China (31730104, 31770411, 31870396, 31872247, and 32071495); the National Key Program of Research and Development, Ministry of Science and Technology (2016YFC0503200); the Biodiversity Survey and Assessment Project of the Ministry of Ecology and Environment, China (2019HJ2096001006); and the Innovation Capability Support Program of Shaanxi (2021KJXX-026).

\section{References}

1. Ni X, Wang Y, Hu Y, and Li C. A euprimate skull from the early Eocene of China. Nature. 2004; 427: 65-68. 
2. Bowen GJ, Clyde WC, Koch PL, Ting SY, Alroy J, Tsubamoto T, et al Mammalian dispersal at the Paleocene/Eocene boundary. Science. 2002; 295: 2062-2065

3. Ni X, Gebo D, Dagosto M, Meng J, Tafforeau P, Flynn J, and Beard K. The oldest known primate skeleton and early haplorhine evolution. Nature. 2013 498: 60-64.

4. Goodman M, Porter CA, Czelusniak J, Page SL, Schneider H, Shoshani J, et al. Toward a phylogenetic classification of Primates based on DNA evidence complemented by fossil evidence. Mol Phylogenet Evol. 1998; 9: 585-598.

5. Stewart C-B and Disotell TR. Primate evolution - in and out of Africa. Current Biology. 1998; 8: R582-R588.

6. Roos C, Kothe M, Alba DM, Delson E and Zinner D. The radiation of macaques out of Africa: Evidence from mitogenome divergence times and the fossil record. J Hum Evol. 2019; 133: 114-132.

7. Roos C, Zinner D, Kubatko LS, Schwarz C, Yang MY, Meyer D, et al. Nuclear versus mitochondrial DNA: evidence for hybridization in colobine monkeys. BMC Evolutionary Biology. 2011; 11: 77.

8. Li BG, He G, Guo ST, Hou R, Huang K, Zhang P, et al. Macaques in China: Evolutionary dispersion and subsequent development. American Journal of Primatology. 20020; 82: e23142.

9. Delson E. Evolutionary history of the Cercopithecidae. Contrib Primatol. 1975; 5: 167-217.

10. Fa J. The genus Macaca: a review of taxonomy and evolution. Mammal Review. 1989; 19: 45-81.

11. Delson E. Fossil macaques, phyletic relationships and a scenario of deployment. In The Macaques. Studies in Ecology, Behavior, and Evolution D. Lindburg, ed. (New York: van Nostrand Rheinhold). 1980: 10-30

12. Abegg $C$ and Thierry $B$. Macaque evolution and dispersal in insular southeast Asia. Biological Journal of the Linnean Society. 2002; 75: 555-576.

13. Tosi AJ, Morales JC, Melnick DJ. Paternal, maternal, and biparental molecular markers provide unique windows onto the evolutionary history of macaque monkeys. Evolution. 2003; 57: 1419-1435.

14. Li B, Li M, Li J, Fan P, Ni Q, Lu J, et al. The primate extinction crisis in China: immediate challenges and a way forward. Biodivers Conserv. 2018; 27: 3301-3327.

15. Delson E. Colobine Monkeys: Their Ecology, Behaviour, and Evolution, (Camridge, United Kingdom: Cambridge University Press). 1994.

16. Heintz E, Brunet M, Battait B. A cercopithecid primate from the late miocene of Molayan, Afghanistan, with remarks on Mesopithecus. International Journal of Primatology. 1981; 2: 273-284.

17. Jablonski N, Kelly S, LJ F, Ji X. The Mio-Pliocene colobine monkey, Mesopithecus, in China. Am. J. Phys. Anthropol. 2011; 144: 174.

18. Roos C, Zinner D, Kubatko LS, Schwarz C, Yang M, Meyer D, et al. Nuclear versus mitochondrial DNA: evidence for hybridization in colobine monkeys. BMC Evolutionary Biology. 2011; 11: 77.

19. Temerin LA. The evolutionary divergence of Old World monkeys and apes. The American Naturalist. 1983; 122: 335-351.

20. Ji X, Jablonski NG, Su DF, Deng C, Flynn LJ, You Y, et al. Juvenile hominoid cranium from the terminal Miocene of Yunnan, China. Chinese Science Bulletin. 2013; 58: 3771-3779.

21. Pilbeam D. Gigantopithecus and the origins of Hominidae. Nature. 1970; 225 516-519.

22. Jin C, Qin D, Pan W, Tang Z, Liu J, Wang Y, et al. A newly discovered Gigantopithecus fauna from Sanhe Cave, Chongzuo, Guangxi, South China Chinese Sci. Bull. 2009; 54: 788-797.

23. Wu R, Han D, Xi Q. Ramapithecus skulls found first time in the world - brief report on excavation of the Lufeeng fossil ape site in the winter of 1980 Chinese Science Bulletin. 1981; 26: 1018-1018.

24. Qi G. First discovery of ursavus in China and notes on other Ursidae specimens from the Ramapithecus fossil site of Lufeng. Acta Anthropologica Sinica. 1984; 3: 53-62.

25. Bocherens H, Schrenk F, Chaimanee $Y$, Kullmer O, Mörike D, Pushkina D, et al. Flexibility of diet and habitat in Pleistocene South Asian mammals: Implications for the fate of the giant fossil ape Gigantopithecus. Quaternary International. 2017; 434: 148-155.

26. Jablonski NG. The response of catarrhine primates to pleistocene environmental fluctuations in East Asia. Primates. 1988; 39: 29-37.

27. Jablonski N, Whitfort M. Environmental change during the Quaternary in East Asia and its consequences for mammals. Records of the Western Australian Museum. 1999: 307-315.

28. Jablonski NG, Whitfort MJ, Roberts-Smith N, Qinqi X. The influence of life history and diet on the distribution of catarrhine primates during the Pleistocene in eastern Asia. J Hum Evol. 2000; 39: 131-157.

29. Andrews P, Johnson R. Gibbons and hominoid ancestors. Taxonomic Tapestries. In The Threads of Evolutionary, Behavioural and Conservation. B.A.a.O. MF, ed. (Canberra: Australian National University Press). 2015

30. Ma S. Probe on the Chinese origin of gibbons (Hylobates). Acta Theriologica Sinica. 1979; 17: 13-23.

31. Jablonski N, Chaplin G. The Fossil Record of Gibbons. In The Gibbons Developments in Primatology: Progress and Prospects, LS Whittaker D., ed. (New York: Springer). 2009: 111-130.

32. Begun D. European Hominoids. In The Primate Fossil Records, H. WC, ed (Cambridge: Cambridge University Press). 2008: 339-368.

33. Reichard U, Hirai H, Barelli C, Barelli C. The Evolution of Gibbons and Siamang. Phylogeny, Morphology, and Cognition, (New York: SpringerVerlag). 2016.

34. Ortiz A, Pilbrow V, Villamil CI, Korsgaard JG, Bailey SE, Harrison T. The Taxonomic and Phylogenetic Affinities of Bunopithecus sericus, a Fossil Hylobatid from the Pleistocene of China. PLoS One. 2015; 10: e0131206.

35. Israfil H, Zehr SM, Mootnick AR, Ruvolo M, Steiper ME. Unresolved molecular phylogenies of gibbons and siamangs (Family: Hylobatidae) based on mitochondrial, $Y$-linked, and $\mathrm{X}$-linked loci indicate a rapid Miocene radiation or sudden vicariance event. Mol Phylogenet Evol. 2011; 58: 447-455.

36. Disotell T. Genetic perspectives on ape and human evolution. In A companion to paleoanthropology, B. DR, ed. (Oxford: Wiley-Blackwell). 2013; 291-305

37. Thinh VN, Mootnick AR, Geissmann T, Li M, Ziegler T, Agil M, et al. Mitochondrial evidence for multiple radiations in the evolutionary history of small apes. BMC Evol Biol. 2010; 10: 74

38. Li C. A Miocene gibbon like primate from Shihhang, Kiangsu Province. Vertebrata Palasiatica. 1978; 16: 187-192.

39. Wu R, Pan Y. A late Miocene Gibbon-like primate from Lufeng, Yunnan Province. Acta Anthropologica Sinica. 1984; 3: 185-194.

40. Wu RK, Pan YR. Preliminary observation on the cranium of Laccopithecus robustus from Lufeng, Yunnan with reference to its phylogenetic relationship. Acta Anthropologica Sinica. 1985; 4: 7-12.

41. Qiu Z, Kuan J. A lower molar of Pliopithecus from Tongxin, Ningxia Hui Autonomous region. Acta Anthropologica Sinica. 1986; 5: 201-207.

42. Gu Y. Preliminary research on the fossil of Pleistocene China. Anthropologica Sinica. 1986; 5: 208-219.

43. Wu YQ, Cui ZJ, Liu GN, Ge DK, Yin JR, Xu QH, et al. Quaternary geomorphological evolution of the Kunlun Pass area and uplift of the QinghaiXizang (Tibet) Plateau. Geomorphology. 2001; 36: 203-216.

44. Wang C, Lu H, Zhang J, Gu Z, He K. Prehistoric demographic fluctuations in China inferred from radiocarbon data and their linkage with climate change over the past 50,000 years. Quaternary Science Reviews. 2014; 98: 45-59.

45. Huang $\mathrm{K}$, Zhang $\mathrm{H}$, Wang $\mathrm{C}$, Hou R, Zhang $\mathrm{P}$, He G, et al. Use of historical and contemporary distribution of mammals in China to inform conservation. Conserv Biol. 2021. 
46. Turvey ST, Crees JJ, Di Fonzo MM. Historical data as a baseline for conservation: reconstructing long-term faunal extinction dynamics in Late Imperial-modern China. Proc Biol Sci. 2015; 282: 20151299.

47. Wu R, Wu X. Paleolithic Site in China (in Chinese), (Shanghai: Shanghai Scientific and Technological Publishing House.). 1999.

48. Shi L, Zhang X, GS. New chronological evidence for the origin of modern humans in China. J Nanjing University (Nat Sci). 2003; 26: 89-94.

49. Pan R, Oxnard C, Grueter CC, Li B, Qi X, He G, et al. A new conservation strategy for China-A model starting with primates. Am J Primatol. 2016; 78 1137-1148.

50. Zhao X, Ren B, Garber PA, Li X, Li M, Vaclavik T. Impacts of human activity and climate change on the distribution of snub-nosed monkeys in China during the past 2000 years. Diversity and Distributions. 2018; 24: 92-102.

51. Corlett R. The Impact of Hunting on the Mammalian Fauna of Tropical Asian Forests. Biotropica. 2007; 39: 292-303.

52. Zhu Z, Dennell R, Huang W, Wu Y, Qiu S, Yang S, et al. Hominin occupation of the Chinese Loess Plateau since about 2.1 million years ago. Nature. 2018; 559: 608-612.

53. Zhu RX, Hoffman KA, Potts R, Deng CL, Pan YX, Guo B, et al. Earliest presence of humans in northeast Asia. Nature. 2001; 413: 413-417.

54. Ao H, Dekkers MJ, Wei Q, Qiang X, Xiao G. New evidence for early presence of hominids in North China. Sci Rep. 2013; 3: 2403.
55. Zhu RX, Potts R, Pan YX, Yao HT, Lu LQ, Zhao X, et al. Early evidence of the genus Homo in East Asia. J Hum Evol. 2008; 55: 1075-1085.

56. Zhu R, An Z, Potts R, Hoffman KA. Magnetostratigraphic dating of early humans in China. Earth-Science Reviews. 2003; 61: 341-359.

57. Zhu RX, Potts R, Xie F, Hoffman KA, Deng CL, Shi CD, et al. New evidence on the earliest human presence at high northern latitudes in northeast Asia. Nature. 2004; 431: 559-562.

58. Rosenberg $\mathrm{K}$ and Wu X. A river runs through it: modern human origins in East Asia. In The Origins of Modern Humans: Biology Reconsidered, FH Smith, Ahern JCM, ed. (Hoboken NJ: Wiley-Blackwell). 2013.

59. Stewart JR, Stringer CB. Human evolution out of Africa: the role of refugia and climate change. Science. 2012; 335: 1317-1321.

60. Qiu J. The forgotten continent, fossil finds in China are challenging ideas about the evolution of modern humans and our closest relatives. Nature. 2016: 218-220

61. Ji Q, Wu WS, Ji YN, Li Q, Ni XJ. Late Middle Pleistocene Harbin cranium represents a new Homo species. The Innovation. 2021: 100132.

62. Wen RS. Geographical Distribution of Wild Animals in Ancient China, (Jinan (in Chinese): Academic Press in Shandong). 2013.

63. Zhu ZY, Dennell R, Huang WW, Wu Y, Rao ZG, Qiu SF, et al. New dating of the Homo erectus cranium from Lantian (Gongwangling), Chi. 2015; 78: 144-157. 